\title{
Reduction of photosynthesis in sun leaves of Gossypium hirsutum L under conditions of high light intensities and suboptimal leaf temperatures
}

\author{
M Königer * $\mathrm{K}$ Winter * \\ Lehrstuhl für Botanik II, Julius-von-Sachs Institut für Biowissenschaften, Mittlerer Dallenbergweg 64, \\ D-97082 Würzburg, Germany
}

(Received 20 December 1992; accepted 30 April 1993)

\begin{abstract}
Summary - Attached sun leaves of cotton (Gossypium hirsutum $L$ var Delta Pine 61) were enclosed in a gas exchange cuvette and exposed for $4 \mathrm{~d}$ to either 1000 or $1800 \mu \mathrm{mol}$ photons $\mathrm{m}^{-2} \mathrm{~s}^{-1}$ and a series of air temperatures $\left(35,30,25\right.$ and $\left.20^{\circ} \mathrm{C}\right)$ during the 12-h light periods. The temperature during the 12 -h dark periods was maintained at $25^{\circ} \mathrm{C}$. The highest $\mathrm{CO}_{2}$ assimilation rates $\left(A_{\max }: \approx 30 \mu \mathrm{mol} \mathrm{CO} \mathrm{CO}^{-2} \mathrm{~s}^{-1}\right)$ were reached at $1800 \mu \mathrm{mol}$ photons $\mathrm{m}^{-2} \mathrm{~s}^{-1}$ and air temperatures of 30 and $35^{\circ} \mathrm{C}$. At $30^{\circ} \mathrm{C}$ and $1000 \mu$ mol photons $\mathrm{m}^{-2} \mathrm{~s}^{-1}, A_{\max }$ was reduced by $20 \%$. At both light intensities $A_{\max }$ and stomatal conductance declined with decreasing temperatures. The reduction in $A_{\max }$ was most severe at $1800 \mu \mathrm{mol}$ photons $\mathrm{m}^{-2} \mathrm{~s}^{-1}$ and $20^{\circ} \mathrm{C}$. The leaves exposed to these conditions also exhibited marked decreases in rates of $\mathrm{CO}_{2}$-saturated photosynthetic $\mathrm{O}_{2}$ evolution under light saturation $\left(P S_{\max }\right)$ and light limitation (Ø) and in $F_{\mathrm{V}} / F_{\mathrm{M}}$. These 3 parameters were less severely affected by treatment with medium light intensity $(1000 \mu \mathrm{mol}$ photons $\mathrm{m}^{-2} \mathrm{~s}^{-1}$ ). The data show that when sun leaves of cotton are exposed for short periods of time to temperatures only slightly suboptimal for photosynthesis, high light intensities can cause marked photoinhibition.
\end{abstract}

Gossypium hirsutum $=$ cotton $/$ photoinhibition of photosynthesis $/$ temperature

Résumé - Réduction de la photosynthèse chez les feuilles héliophiles de Gossypium hirsutum $L$ sous des conditions de haute intensité de lumière et de température foliaire suboptimale. Des feuilles héliophiles de cotonnier, attachées à la plante (Gossypium hirsutum $L$ var Delta Pine 61) ont été mises dans une cuvette d'échange gazeux et exposées pendant 4 jours à 1000 ou $1800 \mu \mathrm{mol}$ photons $\mathrm{m}^{-2} \mathrm{~s}^{-1}$ et à une série de températures d'air ( $35^{\circ}$, $30^{\circ}, 25^{\circ}, 20^{\circ} \mathrm{C}$ ) pendant les périodes d'éclairement de $12 \mathrm{~h}$. La température, pendant les périodes obscures de $12 \mathrm{~h}$, a été maintenue à $25^{\circ} \mathrm{C}$. Les plus hauts taux d'assimilation de $\mathrm{CO}_{2}\left(A_{\max }\right.$ : env $\left.30 \mu \mathrm{mol} \mathrm{CO}_{2} \mathrm{~m}^{-2} \mathrm{~s}^{-1}\right)$ ont été atteint à $1800 \mu \mathrm{mol}$ photons $\mathrm{m}^{-2} \mathrm{~s}^{-1}$ et des températures de l'air de $30^{\circ}$ et $35^{\circ} \mathrm{C}$. $\dot{A} 30^{\circ} \mathrm{C}$ et $1000 \mu \mathrm{mol}$ photons $\mathrm{m}^{-2} \mathrm{~s}^{-1} \mathrm{~A}_{\max }$ a diminué de $20 \%$. Aux 2 intensités de lumière, $\mathrm{A}_{\max }$ et la conductivité stomatique ont diminué avec la baisse des températures. La réduction en $\mathrm{A}_{\max }$ a été très sévère à $1800 \mu \mathrm{mol}$ photons $\mathrm{m}^{-2} \mathrm{~s}^{-1}$ et $20^{\circ} \mathrm{C}$. Les feuilles exposées à ces conditions ont aussi montré des baisses importantes dans les taux d'évolution d' $\mathrm{O}_{2}$ photosynthétique, à saturation en $\mathrm{CO}_{2}$, sous conditions de saturation en lumière $\left(\mathrm{PS}_{\max }\right)$, de limitation en lumière (Ø) et en $\mathrm{F}_{\mathcal{V}} \mathrm{F}_{M}$. Ces 3 paramètres ont été moins sévèrement affectés par le traitement de lumière à moyenne intensité (1 $000 \mu \mathrm{mol}$ photons $\left.\mathrm{m}^{-2} \mathrm{~s}^{-1}\right)$. Les données montrent que, lorsque les feuilles héliophiles du cotonnier sont exposées pendant de courtes périodes de temps à des températures seulement légèrement suboptimales pour la photosynthèse, les hautes intensités de lumière peuvent provoquer une photo-inhibition importante.

Gossypium hirsutum = coton / photo-inhibition de la photosynthèse / température

\footnotetext{
* Present address: Smithsonian Tropical Research Institute, PO Box 2072, Balboa, Republic of Panama. Abbreviations: $A_{\max }$, maximum $\mathrm{CO}_{2}$ assimilation rate measured at ambient $\mathrm{CO}_{2}$ during a given light period; $F_{\mathrm{V}} / F_{\mathrm{M}}$, ratio of variable to maximum fluorescence yield; $p_{i}$, intercellular $\mathrm{CO}_{2}$ partial pressure; $p_{\mathrm{a}}$, ambient $\mathrm{CO}_{2}$ partial pressure; $P F D$, photon flux density (400$700 \mathrm{~nm}$ ); $P S_{\max }$, photosynthetic capacity, maximum rate of $\mathrm{O}_{2}$ evolution measured under saturating light and $\mathrm{CO}_{2} \mathrm{conditions;} \varnothing$, photon use efficiency of photosynthetic $\mathrm{O}_{2}$ evolution measured in saturating $\mathrm{CO}_{2}$ and based on absorbed red light $(630-700 \mathrm{~nm})$.
} 


\section{INTRODUCTION}

Photosynthesis, especially of tropical species, is known to be adversely affected by chilling temperatures, which are considered as those between 0 and $12^{\circ} \mathrm{C}$ (Öquist et al, 1987). In combination with high light intensities these low temperatures may result in severe photoinhibition of photosynthesis (Taylor and Rowley, 1971; Baker et al, 1983; Long et al, 1983; Powles et al, 1983; Martin and Ort, 1985; Greer, 1988; Somersalo and Krause, 1990). Photoinhibition is characterized by reductions in both light-limited and light-saturated rates of photosynthesis (Walker and Osmond, 1986) and the fluorescence parameter $F_{\mathrm{V}} / F_{\mathrm{M}}$, a measure of the photochemical efficiency of PS II (Kitajima and Butler, 1975). Some investigations on plants grown under low to moderate light intensity (Ögren et al, 1984; Greer et al, 1986; Greer, 1988; Gong and Nilsen, 1989; Rosenqvist et al, 1991) and even high light intensity (Ögren and Sjöström, 1990) suggest that photoinhibition can also be induced by temperatures higher than those in the typical chilling range.

We have previously reported with cotton that temperatures far above the chilling range, when combined with high photon flux densities equivalent to full sunlight, led to severely reduced dry matter production (Königer and Winter, 1991; Winter and Königer, 1991). Although there was evidence that these reductions were partially related to high irradiance stress, it was difficult in these long-term studies with whole plants to differentiate between direct photoinhibitory effects and other possible inhibitory factors such as end-product inhibition of photosynthesis (Harris et al, 1983; Stitt, 1991). Therefore we initiated a series of short-term experiments with individual cotton leaves to determine whether reductions in photosynthesis at only slightly suboptimal temperatures were directly correlated with parameters that reflected photoinhibition.

\section{MATERIAL AND METHODS}

\section{Plant material}

Cotton seedlings (Gossypium hirsutum L var Delta Pine 61) were grown in 18-I pots in a mixture of clay and high moor peat (Einheitserde zum Pikieren, Typ $P$, Gebrüder Patzer KG, Sinntal-Jossa, FRG) up to a size when the primary leaf was $20 \mathrm{~cm}^{2}$ and the first fo- liar leaf was $6 \mathrm{~cm}^{2}$. These plants were then exposed in controlled-environment chambers (for details see Winter and Königer, 1991) for $16 \mathrm{~d}$ in the following conditions: $33 / 25^{\circ} \mathrm{C}$ (day/night temperature) and $1500 \mu \mathrm{mol}$ photons $\mathrm{m}^{-2} \mathrm{~s}^{-1}$ during $12-\mathrm{h}$ light periods. The soil was kept well watered and pots were flushed every other day with 2 I nutrient solution containing $12 \mathrm{mM} \mathrm{NO}_{3}^{-}$ (Wong, 1979). Experimental treatments were initiated following these 16 -d cultivation periods.

\section{$\mathrm{CO}_{2}$ exchange}

Leaf gas exchange was determined continuously throughout the 4-d treatments using an open gas exchange system (Winter and Schramm, 1986). Measurements were made on recently expanded attached single leaves (4th leaf following the primary leaf). They were enclosed in a gas-exchange cuvette (GWK 3, 19.5-12.0-9.5 $\mathrm{cm}^{3}$; Fa Walz, Effeltrich, FRG) through which air containing $35 \mathrm{~Pa} \mathrm{CO}$ and $21 \mathrm{kPa} \mathrm{O}_{2}$ and with a dew-point of $5^{\circ} \mathrm{C}$ was supplied at a rate of 6.6 । min-1. During photosynthetic $\mathrm{CO}_{2}$ uptake, the $\mathrm{CO}_{2}$ partial pressure in the air surrounding the leaf decreased by at most $3 \mathrm{~Pa}$. The rest of the plant was maintained at $\approx 30 / 25^{\circ} \mathrm{C}$ (day/night temperature) throughout all treatments. Net $\mathrm{CO}_{2}$ assimilation rate, conductance to water vapor transfer and internal $\mathrm{CO}_{2}$ partial pressure were calculated according to Von Caemmerer and Farquhar (1981).

\section{$\mathrm{O}_{2}$ exchange}

Photosynthetic $\mathrm{O}_{2}$ evolution from leaf discs $\left(10 \mathrm{~cm}^{2}\right)$ was determined at $25^{\circ} \mathrm{C}$ and $5 \% \mathrm{CO}_{2}, 20 \% \mathrm{O}_{2}, 75 \%$ $\mathrm{N}_{2}$ with an LD-2 $\mathrm{O}_{2}$ electrode unit and an LS-2 light source (Hansatech, King's Lynn, Norfolk, UK). Photosynthetic capacities $\left(P S_{\max }\right)$ were measured at 1600 $\mu \mathrm{mol}$ photons $\mathrm{m}^{-2} \mathrm{~s}^{-1}$. Photon use efficiencies (Ø) were based on absorbed red light (RG 630; Schott Glaswerke, Mainz, FRG). The light source was calibrated with a quantum sensor (LI-190 SB, LI-Cor, Lincoln, NE, USA). Absorbtance $(630-700 \mathrm{~nm})$ was determined with an integrating sphere (LI-1800-12, $\mathrm{Li}$-Cor) connected to a spectroradiometer (LI-1800, Li-Cor).

\section{Fluorescence}

Chl a fluorescence of leaf discs excised from the treated (attached) leaves was measured at room temperature using a pulse amplitude modulation fluorometer (PAM 101; Fa Walz; Schreiber et al, 1986). Samples were taken at the end of 12-h dark periods and enclosed in a brass cuvette. The upper leaf surface was pressed against a Perspex window, which formed the bottom of the chamber lid, in which the fiber-optic 
probe of the fluorometer was fixed. Fluorescence was excited with a measuring beam of weak light from a pulsed light-emitting diode to obtain $F_{0}$, the fluorescence level when all PS II reaction centers are open. Maximum fluorescence, $F_{M}$, was determined by applying a 1-s pulse of saturating light. The variable fluorescence, $F_{V}$, is given by the difference between $F_{M}$ and $F_{0}$. The photochemical efficiency of PS II, expressed as $F_{\mathrm{V}} / F_{\mathrm{M}}$, was calculated according to Kitajima and Butler (1975).

\section{Pigments and carbohydrates}

Contents of total chlorophyll $(a+b)$ and total carotenoids of leaf discs were determined in $80 \%$ acetone according to Röbbelen (1957) including the suggested changes of Metzner et al (1965). Soluble and insoluble sugars were determined using the anthrone test (Morris, 1948).

\section{RESULTS}

\section{Gas exchange}

Leaves that had developed in high light (1500 $\mu \mathrm{mol}$ photons $\mathrm{m}^{-2} \mathrm{~s}^{-1}$ ) and at $33 / 25^{\circ} \mathrm{C}$ (day/night temperature) were exposed for $4 d$ to either $1800 \mu \mathrm{mol}$ photons $\mathrm{m}^{-2} \mathrm{~s}^{-1}$ (high PFD) or 1000 $\mu \mathrm{mol}$ photons $\mathrm{m}^{-2} \mathrm{~s}^{-1}$ (medium PFD) and day/ night temperatures of either 35/25, 30/25, 25/25 or $20 / 25^{\circ} \mathrm{C}$. Figures 1 to 4 show representative day courses of leaf temperatures and various gas exchange parameters for cotton leaves during these 4-d treatments. Leaf temperatures were maintained within $\pm 1^{\circ} \mathrm{C}$ of the air temperatures between 20 and $30^{\circ} \mathrm{C}$ and were $\approx 33$ at $35^{\circ} \mathrm{C}$ air temperature. Leaves exposed to 1800 $\mu \mathrm{mol}$ photons $\mathrm{m}^{-2} \mathrm{~s}^{-1}$ and $30^{\circ} \mathrm{C}$ (fig 1) or $35^{\circ} \mathrm{C}$ (not shown), conditions which are close to those the plants experienced during their development, showed maximum $\mathrm{CO}_{2}$ assimilation rates $\left(A_{\max }\right)$ of $\approx 30 \mu \mathrm{mol} \mathrm{m}^{-2} \mathrm{~s}^{-1}$, which were reached 2-5 $\mathrm{h}$ after onset of the light. Photosynthetic rates thereafter gradually declined by $\approx 25 \%$. This pattern of $\mathrm{CO}_{2}$ gas exchange was similar each day for 30 and $35^{\circ} \mathrm{C}$ throughout the 4-d treatment.

Reducing the light intensity from 1800 to $1000 \mu \mathrm{mol}$ photons $\mathrm{m}^{-2} \mathrm{~s}^{-1}$ (fig 2) as well as lowering the temperature from $30^{\circ}$ to $25^{\circ}$ or $20^{\circ} \mathrm{C}$ at either light intensity (figs 3 and 4) resulted in an immediate and marked decline in $\mathrm{CO}_{2}$ assimilation rates, which were then maintained throughout the remainder of the experimental period. There was a closer correlation between changes in $\mathrm{CO}_{2}$ assimilation rates and leaf conductance in the high-temperature than in the low-temperature treatments. Irrespective of light

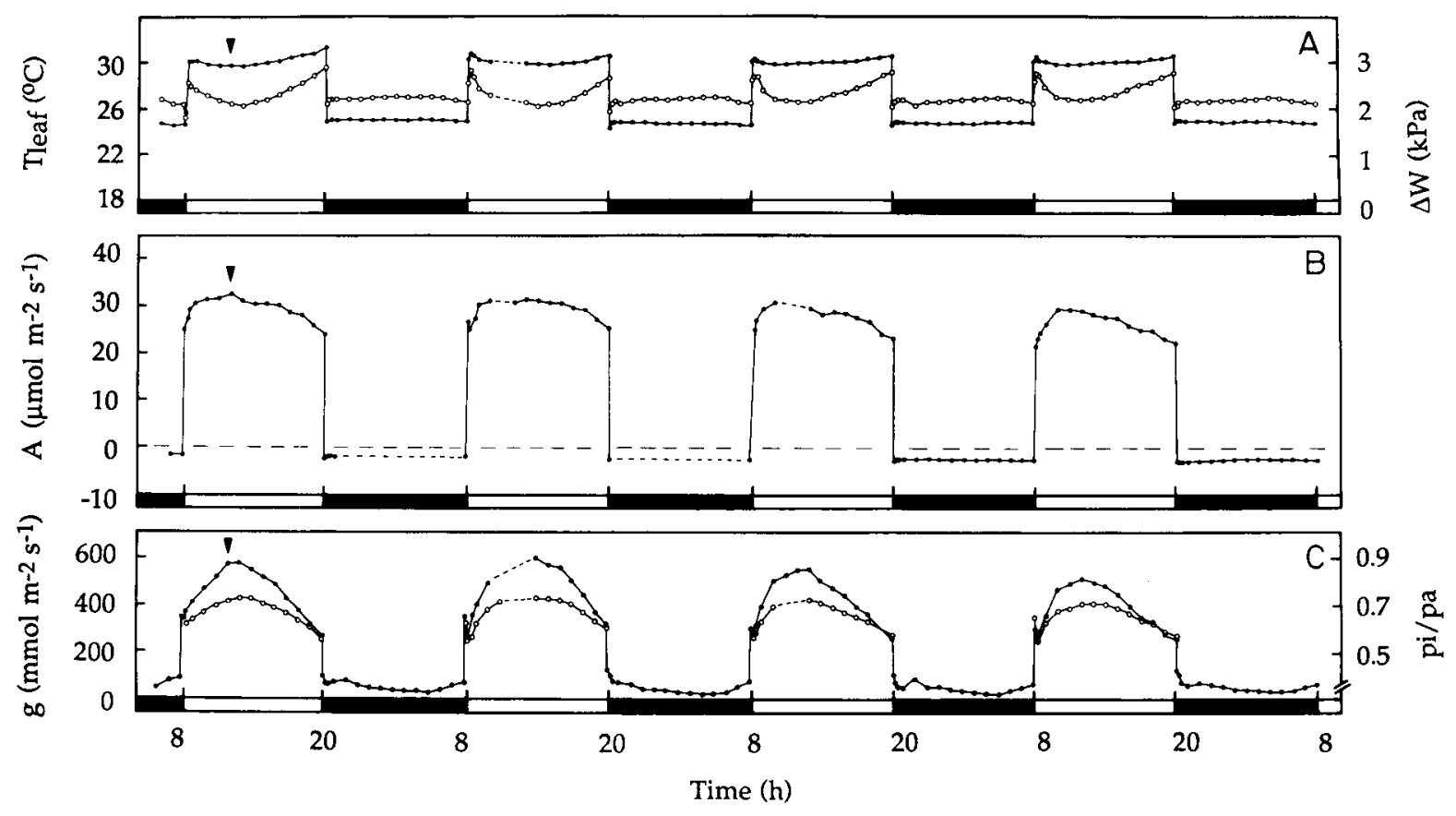

Fig 1. Day courses of leaf temperature $\left(T_{\text {leaf }}, \cdot\right)$, leaf-air vapour pressure deficit $(\Delta W, 0), \mathrm{CO}_{2}$ assimilation rate $(\mathrm{A}, \cdot)$, conductance $(\mathrm{g}, \cdot)$ and the ratio of internal to external $\mathrm{CO}_{2}$ partial pressure $\left(p_{1} / p_{\mathrm{a}}, 0\right)$ of sun leaves of Gossypium hirsutum. Leaves were exposed for $4 \mathrm{~d}$ to $1800 \mu \mathrm{mol}$ photons $\mathrm{m}^{-2} \mathrm{~s}^{-1}$ and $30^{\circ} \mathrm{C}$ during the 12 -h light periods and $25^{\circ} \mathrm{C}$ during the dark periods. 

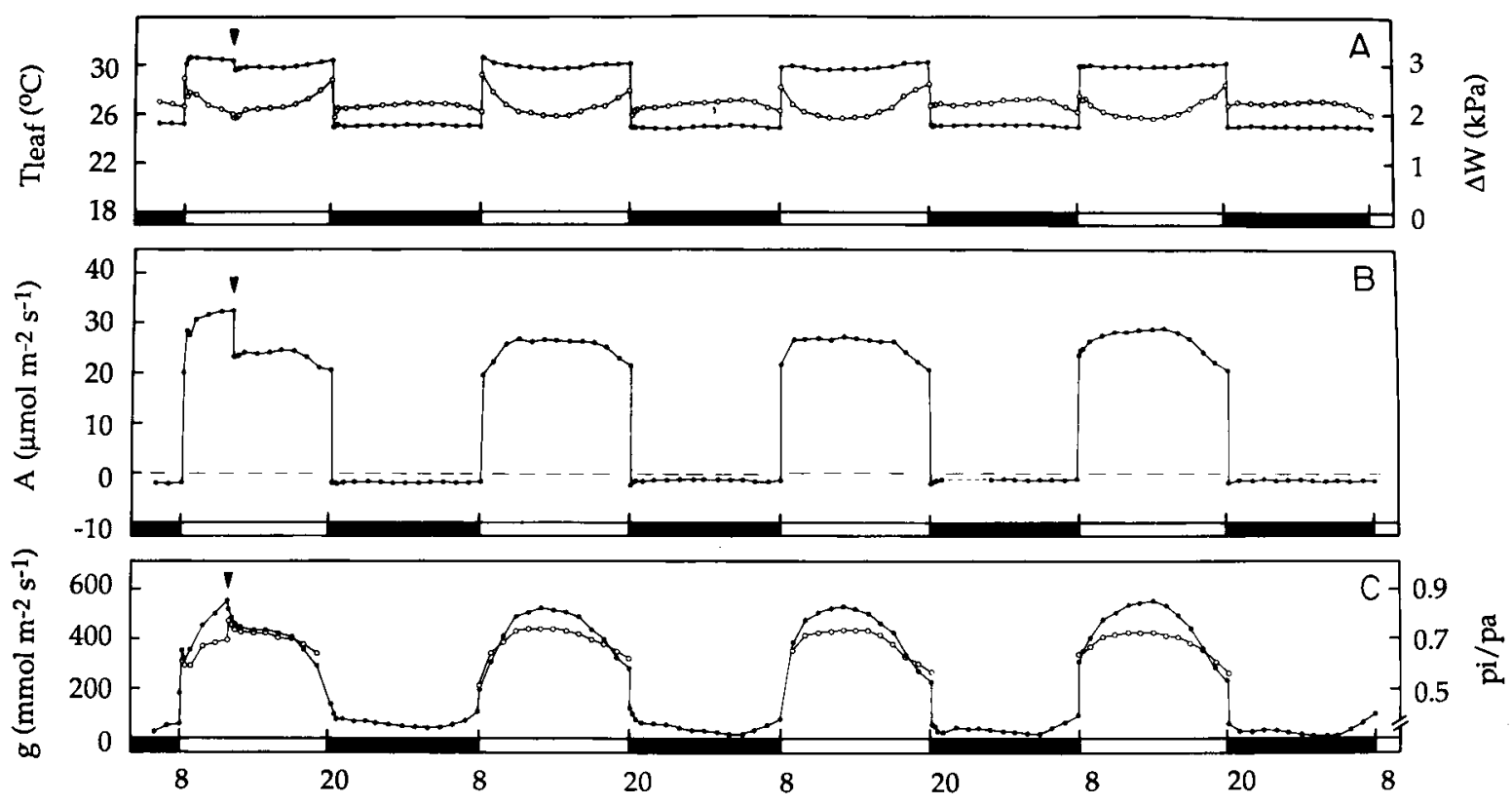

Time (h)

Fig 2. As in figure 1 , but after the initial $4 \mathrm{~h}$ of the light period on $\mathrm{d} 1$ at $1800 \mu \mathrm{mol}$ photons $\mathrm{m}^{-2} \mathrm{~s}^{-1}$ and $30^{\circ} \mathrm{C}$, the light intensity was reduced to $1000 \mu \mathrm{mol}$ photons $\mathrm{m}^{-2} \mathrm{~s}^{-1}$ (arrow). The temperature during the 12 -h dark periods was $25^{\circ} \mathrm{C}$.

and temperature conditions during a given treatment the ratio of internal/external $\mathrm{CO}_{2}$ partial pressure $\left(p_{1} / p_{\mathrm{a}}\right)$ paralleled the changes in conductance and reached the highest values in the middle of the light periods.
Figure 5 summarizes gas exchange parameters during all 4-d treatments expressed as percentage of the values at the beginning of the experiments $(d 1,12.00 \mathrm{~h}) . A_{\max }$, the maximum rate of net $\mathrm{CO}_{2}$ assimilation during a given light

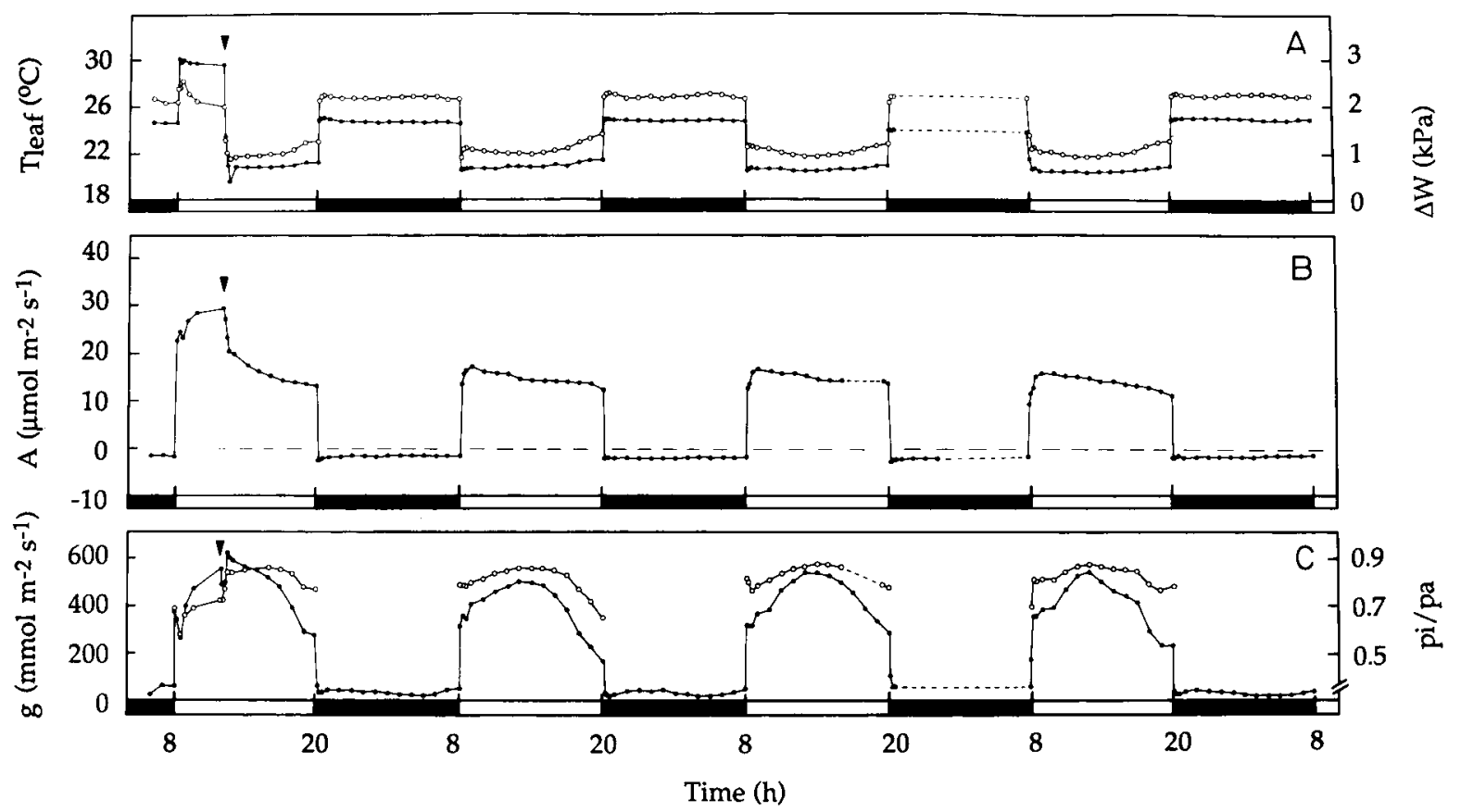

Fig 3. As in figure 1 , but after the initial $4 \mathrm{~h}$ of the light period on d 1 at $1800 \mu \mathrm{mol}$ photons $\mathrm{m}^{-2} \mathrm{~s}^{-1}$ and $30^{\circ} \mathrm{C}$, the temperature during the light period was reduced to $20^{\circ} \mathrm{C}$ (arrow). The temperature during the 12 -h dark periods was $25^{\circ} \mathrm{C}$. 


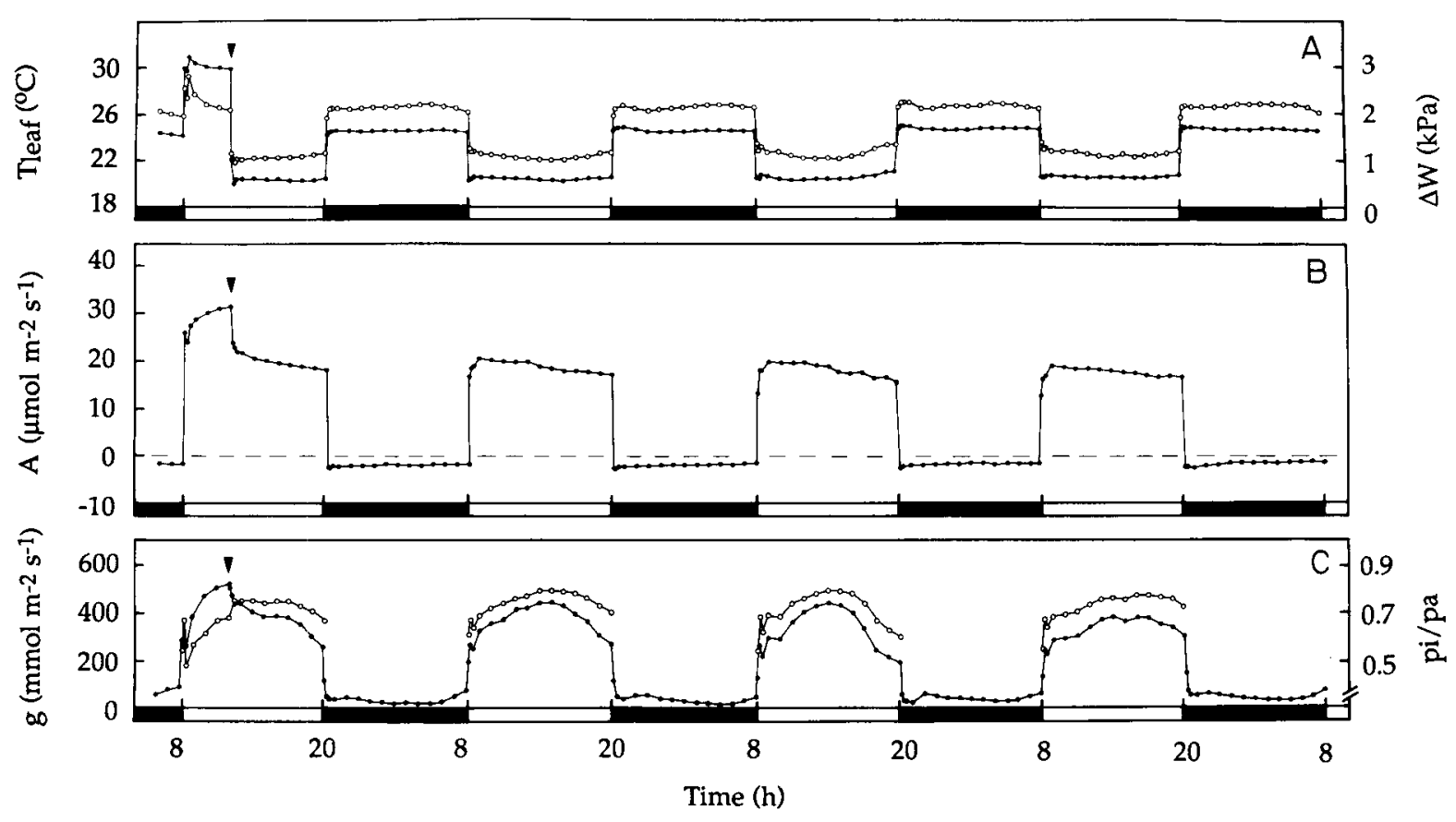

Fig 4. As in figure 1 , but after the initial $4 \mathrm{~h}$ of the light period on $\mathrm{d} 1$ at $1800 \mu \mathrm{mol}$ photons $\mathrm{m}^{-2} \mathrm{~s}^{-1}$ and $30^{\circ} \mathrm{C}$, the temperature and light intensity were reduced to $20^{\circ} \mathrm{C}$ and $1000 \mu \mathrm{mol}$ photons $\mathrm{m}^{-2} \mathrm{~s}^{-1}$, respectively (arrow). The temperature during the 12-h dark periods was $25^{\circ} \mathrm{C}$.

period, remained high throughout the $4 \mathrm{~d}$ at $1800 \mu \mathrm{mol}$ photons $\mathrm{m}^{-2} \mathrm{~s}^{-1}$ and 30 and $35^{\circ} \mathrm{C}$. Decreasing the temperature to $20^{\circ} \mathrm{C}$ for high light treated plants resulted in a much larger percentage inhibition of $\mathrm{CO}_{2}$ assimilation rate than in plants under medium light, and rates in high light dropped below those in medium light. The reduction in $A_{\max }$ at low temperatures could not be explained by stomatal closure, because the ratio of internal to external $\mathrm{CO}_{2}$ partial pressure increased slightly with decreasing temperatures. Changes in $A_{\max }$ were linearly correlated with total carbon gain during $12 \mathrm{~h}$ light periods for all treatments (fig 6).

\section{Photosynthetic oxygen evolution and $\mathrm{F}_{V} / \mathrm{F}_{M}$}

Photosynthetic competence as shown by $P S_{\max }$, $\varnothing$ and $F_{V} / F_{M}$ was determined on leaf samples harvested at the end of the dark period of $d 4$ (fig 7). At $30^{\circ} \mathrm{C}$ in high light, $P S_{\max }$ was high and $\varnothing$ and $F_{\mathrm{V}} / F_{\mathrm{M}}$ were close to those generally observed in healthy, non-photoinhibited $\mathrm{C}_{3}$ leaves (Björkman and Demmig, 1987).

With decreasing temperatures in high light, $P S_{\max }, \varnothing$ and $F_{\mathrm{V}} / F_{\mathrm{M}}$ decreased by 18,24 and
$5 \%\left(25^{\circ} \mathrm{C}\right)$ and 31,38 and $39 \%\left(20^{\circ} \mathrm{C}\right)$, respectively, whereas an increase in temperature to $35^{\circ} \mathrm{C}$ had only little impact on these parameters. After $4 \mathrm{~d}$ in medium light at $30^{\circ} \mathrm{C}$ the values were not markedly different from those measured in high light. $P S_{\max }, \varnothing$ and $F_{\mathrm{V}} / F_{\mathrm{M}}$ were reduced by 4,5 and $8 \%$, respectively, as treatment temperature was lowered to $20^{\circ} \mathrm{C}$.

Leaves exposed to $1800 \mu \mathrm{mol}$ photons $\mathrm{m}^{-2} \mathrm{~s}^{-1}$ and $20^{\circ} \mathrm{C}$ showed signs of photooxidation (table I). Total chlorophyll content was reduced by $\approx 26 \%$ in comparison to the $30^{\circ} \mathrm{C}$ treatment in high light.

\section{Carbohydrates}

For 2 of the experimental treatments $(1800 \mu \mathrm{mol}$ $\mathrm{m}^{-2} \mathrm{~s}^{-1}, 30$ and $20^{\circ} \mathrm{C}$ ), carbohydrate contents were measured to investigate the possible role of feedback inhibition of photosynthesis in these treatments. On d 4, at the end of light and dark periods, there was no clear difference in the total carbohydrate content between leaves exposed to the 2 temperature treatments (table II). 

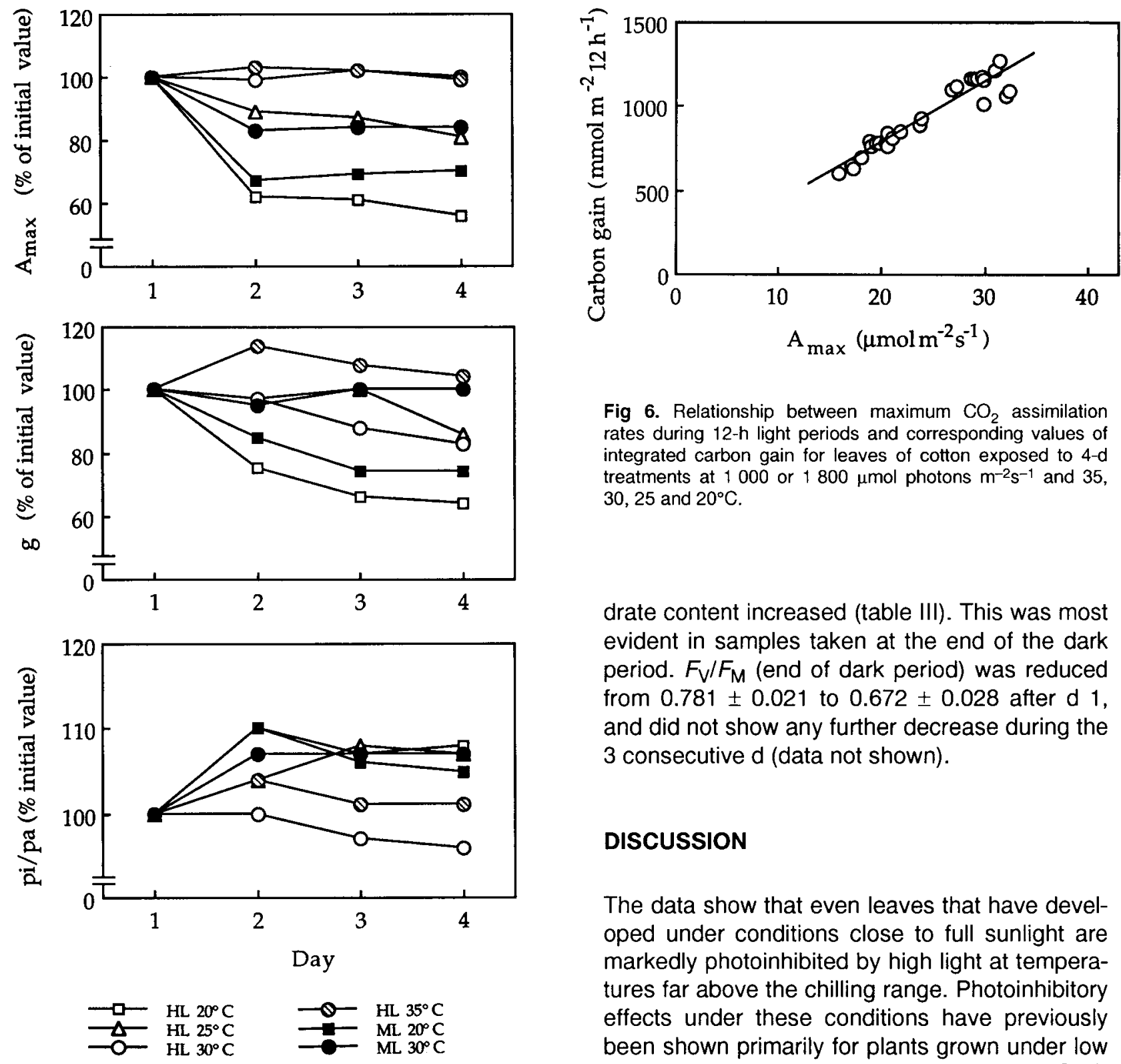

drate content increased (table III). This was most evident in samples taken at the end of the dark period. $F_{\mathrm{V}} / F_{\mathrm{M}}$ (end of dark period) was reduced from $0.781 \pm 0.021$ to $0.672 \pm 0.028$ after $d 1$, and did not show any further decrease during the 3 consecutive d (data not shown).

\section{DISCUSSION}

The data show that even leaves that have developed under conditions close to full sunlight are markedly photoinhibited by high light at temperatures far above the chilling range. Photoinhibitory effects under these conditions have previously been shown primarily for plants grown under low light intensities $\left(100-300 \mu \mathrm{mol}\right.$ photons $\mathrm{m}^{-2} \mathrm{~s}^{-1}$;

Fig 5. Changes in gas exchange parameters of sun leaves of Gossypium hirsutum during 4-d treatments. Leaves were exposed to $1800 \mu \mathrm{mol}$ photons $\mathrm{m}^{-2} \mathrm{~s}^{-1}$ ( $\mathrm{HL}$ ) or $1000 \mu \mathrm{mol}$ photons $\mathrm{m}^{-2} \mathrm{~s}^{-1}$ (ML) at air temperatures of $35,30,25$ and $20^{\circ} \mathrm{C}$, respectively. Maximum $\mathrm{CO}_{2}$ assimilation rates $\left(A_{\max }\right)$ of each photoperiod are expressed as percent of the initial value $(12.00 \mathrm{~h}$ on $\mathrm{d} 1)$. Corresponding values for conductance $(\mathrm{g})$ and the ratio of internal to external $\mathrm{CO}_{2}$ partial pressure $\left(p_{1}\right)$ $p_{a}$ ) are also expressed as percent of the initial value. Data for d 2, 3 and 4 are the means of 2-3 experiments. The SD, which did not deviate from $\pm 13 \%$, is not shown. $100 \% A_{\max }=$ $30.45 \pm 1.95 \mu \mathrm{mol} \mathrm{m} \mathrm{m}^{-2} \mathrm{~s}^{-1}(n=12), 100 \% g=494.89 \pm 63.23$ $\mathrm{mmol} \mathrm{m} \mathrm{m}^{-2} \mathrm{~s}^{-1}(n=12), 100 \% p_{1} / p_{\mathrm{a}}=0.68 \pm 0.03(n=12)$.

In contrast, when whole cotton plants were exposed to high light $\left(1800 \mu \mathrm{mol}\right.$ photons $\left.\mathrm{m}^{-2} \mathrm{~s}^{-1}\right)$ and day/night leaf temperatures of $\approx 20 / 25^{\circ} \mathrm{C}$, for example, conditions similar to those used in one of the single leaf experiments, the total carbohyÖgren et al, 1984; Greer et al, 1986; Greer, 1988; Gong and Nilsen, 1989; Rosenqvist et al, 1991). It is not surprising that such low-light acclimated plants would be highly susceptible to excess light. It is therefore intriguing that in these sun-acclimated leaves of cotton, even a 4-d treatment in high light at $25^{\circ} \mathrm{C}$, only $5^{\circ} \mathrm{C}$ below the optimum temperature for photosynthesis, led to significant reductions in the $\mathrm{CO}_{2}$ saturated rates of $\mathrm{O}_{2}$ evolution under light saturation (18\%) and light limitation (24\%), while $F_{\mathrm{V}} / F_{\mathrm{M}}$ was less affected (5\%) (fig 7). Photoinhibition was also reported for sun leaves of willow when exposed for a few $h$ to high light intensities and temperatures $<23^{\circ} \mathrm{C}$ (Ögren and Sjöström, 1990).

At these relatively high temperatures it is unlikely that phenomena like membrane disruption 

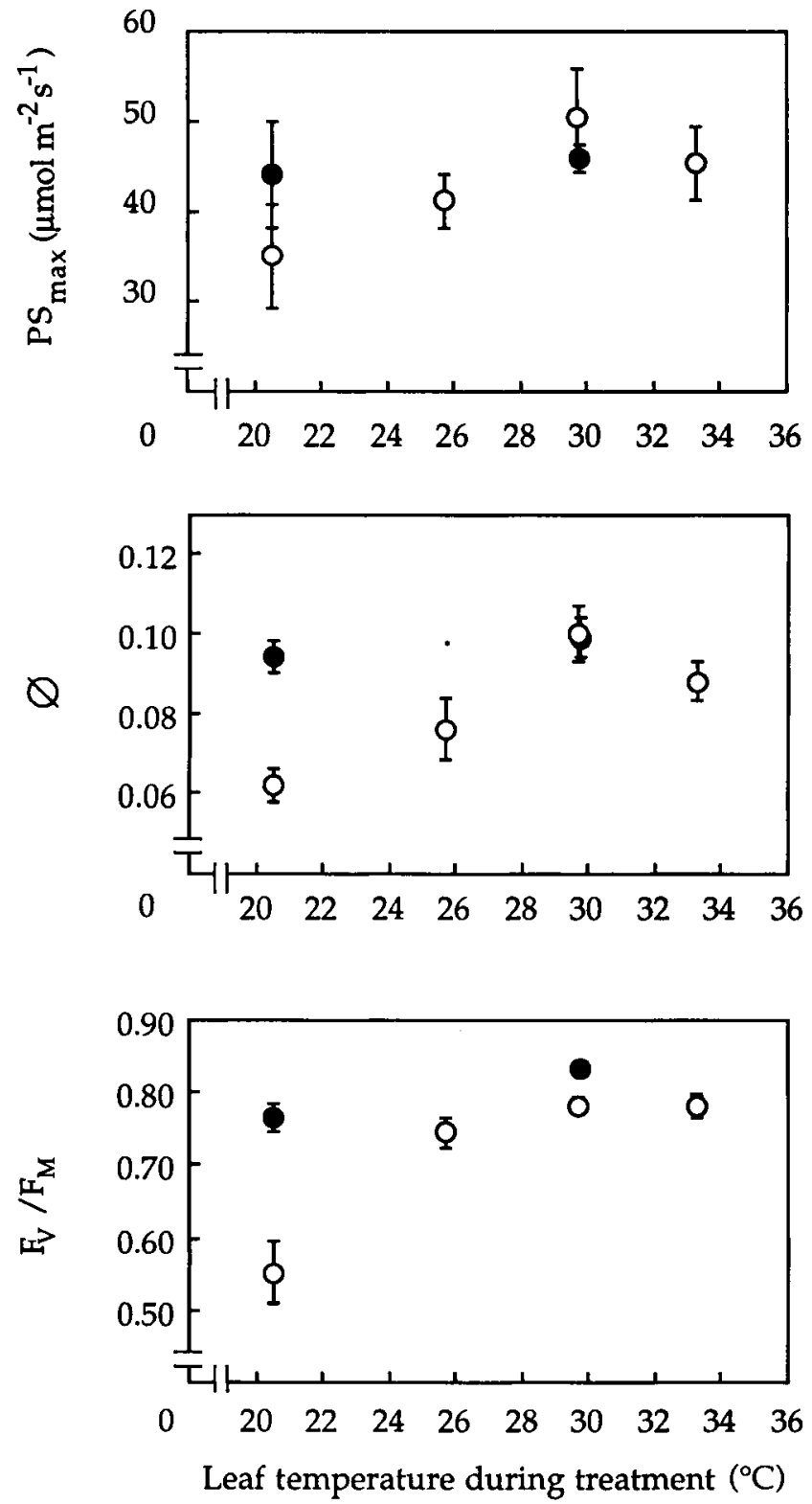

Fig 7. Effects of 4-d treatments at light intensities of 1800 $\mu \mathrm{mol}$ photons $\mathrm{m}^{-2} \mathrm{~s}^{-1}(0)$ and $1000 \mu \mathrm{mol}$ photons $\mathrm{m}^{-2} \mathrm{~s}^{-1}(\cdot)$ at various temperatures on photosynthetic competence of cotton leaves. $P S_{\text {max }}$, light and $\mathrm{CO}_{2}$ saturation rates of $\mathrm{O}_{2}$ evolution; $\varnothing$, photon use efficiency of $\mathrm{CO}_{2}$ saturation rates of $\mathrm{O}_{2}$ evolution; $F_{V} / F_{M}$, photosystem II photon use efficiency. Data are means $\pm \mathrm{SD}(n=3-5)$.

(Rikin et al, 1979; Powles, 1984) and changes in the chloroplast ultrastructure (Taylor and Craig, 1971; Musser et al, 1984; Wise and Naylor, 1987), which have been discussed with regard to chilling injury, are relevant to the results reported here. It is interesting to note that upon a decrease in leaf temperature, $\mathrm{CO}_{2}$ assimilation rates decreased relatively rapidly and remained constant throughout the 4-d experimental periods (figs 3,4$)$. We do not know whether the decreases in the parameters reflecting photosynthetic competence $\left(P S_{\max }, \varnothing, F_{\mathrm{V}} / F_{\mathrm{M}}\right)$, which were determined after $4 \mathrm{~d}$ only, showed similar kinetics, although the experiment with whole cotton plants demonstrated that $F_{\mathrm{V}} / F_{\mathrm{M}}$ was reduced to its final level within $1 \mathrm{~d}$. It is clear that any restriction in carbon metabolism will decrease the use of the products of the light reactions, thus restricting electron flow. In principle, the reductions in $\varnothing, F_{\mathrm{V}} / F_{\mathrm{M}}$ reflect either photodamage to PS II reaction centers or photoprotective mechanisms, ie controlled increase in the rate of dissipation of excitation energy as heat (Demmig-Adams, 1990; Krause and Weis, 1991). We do not know the extent to which these different mechanisms of photoinhibition contribute to the observed decrease of $\varnothing$ and $F_{\mathrm{V}} / F_{\mathrm{M}}$. The decrease in chlorophyll content after $4 \mathrm{~d}$ at $20^{\circ} \mathrm{C}$ and high light suggests that some photodamage had occurred.

These findings on single leaves corroborate previous results from long-term studies on whole cotton plants, in which high light conditions combined with leaf temperatures slightly below $30^{\circ} \mathrm{C}$ led to significant reductions in dry matter production (Königer and Winter, 1991; Winter and Königer, 1991). Because of the complexity of the whole plant system we could not definitively relate the reduction in growth to photoinhibition of photosynthesis. This is emphasized by the data shown in table III, which indicate a possible feedback inhibition of photosynthesis by accumulation of carbohydrates, when whole plants are transferred to reduced temperatures in high light. The low day temperature could decrease the carbohydrate demand in whole plants and inhibit carbohydrate translocation during the night. However, by using single leaves we were able to demonstrate that the reduction in photosynthetic competence in high light and slightly suboptimal leaf temperatures were independent of major changes in carbohydrates (table II).

In conclusion, changes in the velocity of photosynthesis in sun leaves of cotton caused by mild temperature stress in high light over a period of several d, can lead to pronounced photoinhibition of photosynthesis. However, photoinhibition does not seem to be the only factor that contributes to a reduction in growth in high light and temperatures $<30^{\circ} \mathrm{C}$ (Winter and Königer, 1991; Königer and Winter, 1991). 
Table I. Pigment composition of the 4th foliar leaf of Gossypium hirsutum.

\begin{tabular}{|c|c|c|c|c|c|c|c|}
\hline \multirow{2}{*}{$\begin{array}{l}\text { Pigments } \\
\left(\mu g \mathrm{~cm}^{-2}\right)\end{array}$} & $1500 \mu \mathrm{mol} \mathrm{m} \mathrm{m}^{-2} \mathrm{~s}^{-1}$ & \multicolumn{2}{|c|}{$1000 \mu \mathrm{mol} \mathrm{m} \mathrm{m}^{-2} \mathrm{~s}^{-1}$} & \multicolumn{4}{|c|}{$1800 \mu \mathrm{mol} \mathrm{m} \mathrm{m}^{-2} \mathrm{~s}^{-1}$} \\
\hline & Control & $30^{\circ} \mathrm{C}$ & $20^{\circ} \mathrm{C}$ & $35^{\circ} \mathrm{C}$ & $30^{\circ} \mathrm{C}$ & $25^{\circ} \mathrm{C}$ & $20^{\circ} \mathrm{C}$ \\
\hline
\end{tabular}

Chlorophyll (total) $39.33 \pm 1.90 \quad 49.16 \pm 2.18 \quad 38.00 \pm 1.13 \quad 42.40 \pm 2.57 \quad 39.37 \pm 2.17 \quad 40.97 \pm 6.28 \quad 28.94 \pm 1.36$

$\begin{array}{llllllll}\text { Carotenoids (total) } & 8.77 \pm 0.94 & 9.79 \pm 0.25 & 9.24 \pm 1.59 & 8.77 \pm 0.57 & 9.64 \pm 0.44 & 10.47 \pm 2.01 & 7.89 \pm 1.20\end{array}$

Plants were cultivated for $16 \mathrm{~d}$ at $33 / 25^{\circ} \mathrm{C}$ (day/night temperature) and $1500 \mu \mathrm{mol}$ photons $\mathrm{m}^{-2} \mathrm{~s}^{-1}$. Control values were determined at the end of the dark period on $\mathrm{d} 16$. Leaves were then enclosed in a gas-exchange cuvette and exposed for $4 \mathrm{~d}$ to air temperatures of $35,30,25$ and $20^{\circ} \mathrm{C}$ at either 1000 or $1800 \mu \mathrm{mol}$ photons $\mathrm{m}^{-2} \mathrm{~s}^{-1}$. Data are means $\pm \mathrm{SD}(n=4-6)$.

Table II. Carbohydrate contents ( $\mu \mathrm{mol}$ glucose equivalents $\mathrm{g}^{-1} \mathrm{DW}$ ) of the 4 th foliar leaf of Gossypium hirsutum.

\begin{tabular}{|c|c|c|c|c|}
\hline \multirow{2}{*}{$\begin{array}{l}\text { Carbohydrates } \\
\left(\mu \mathrm{mol} g^{-1} D W\right)\end{array}$} & \multicolumn{2}{|c|}{$30 / 25^{\circ} \mathrm{C}$} & \multicolumn{2}{|c|}{$20 / 25^{\circ} \mathrm{C}$} \\
\hline & End of light period & End of dark period & End of light period & End of dark period \\
\hline Total & $1170 \pm 224$ & $434 \pm 187$ & $1258 \pm 295$ & $608 \pm 157$ \\
\hline Soluble & $370 \pm 19$ & $171 \pm 41$ & $522 \pm 103$ & $369 \pm 163$ \\
\hline Insoluble & $800 \pm 212$ & $263 \pm 160$ & $736 \pm 199$ & $263 \pm 160$ \\
\hline
\end{tabular}

Plants were cultivated for $16 \mathrm{~d}$ at $33 / 25^{\circ} \mathrm{C}$ (day/night temperature) and $1500 \mu \mathrm{mol}$ photons $\mathrm{m}^{-2} \mathrm{~s}^{-1}$. Leaves were then exposed to $1800 \mu \mathrm{mol}$ photons $\mathrm{m}^{-2} \mathrm{~s}^{-1}$ and $30 / 25^{\circ} \mathrm{C}$ or $20 / 25^{\circ} \mathrm{C}$ during $12-\mathrm{h} \mathrm{light/12-h}$ dark cycles. Carbohydrates were measured at the end of the 4-d treatments. Data are means $\pm \operatorname{SD}(n=3)$.

Table III. Carbohydrate contents ( $\mu \mathrm{mol}$ glucose equivalents $\mathrm{g}^{-1} \mathrm{DW}$ ) of the 4 th foliar leaf of Gossypium hirsutum, determined at the end of light and dark periods, respectively, during a 4-d treatment.

\begin{tabular}{|c|c|c|c|c|c|}
\hline \multirow[t]{2}{*}{$\begin{array}{l}\text { Carbohydrates } \\
\left(\mu \mathrm{mol} g^{-1} \mathrm{DW}\right)\end{array}$} & \multicolumn{2}{|c|}{$\begin{array}{cc}33 / 25^{\circ} \mathrm{C} & 15^{\star} / 25^{\circ} \mathrm{C} \\
\left(1500 \mu \mathrm{mol} \mathrm{m} \mathrm{m}^{-2} \mathrm{~s}^{-1}\right) & \left(1800 \mu \mathrm{mol} \mathrm{m} \mathrm{m}^{-2} \mathrm{~s}^{-1}\right)\end{array}$} & \multirow[b]{2}{*}{ Day 2} & \multirow[b]{2}{*}{ Day 3} & \multirow[b]{2}{*}{ Day 4} \\
\hline & Control & Day 1 & & & \\
\hline \multicolumn{6}{|c|}{ End of light period } \\
\hline Total & $1181 \pm 60$ & $1413 \pm 77$ & $1455 \pm 276$ & $1523 \pm 45$ & $1682 \pm 269$ \\
\hline Soluble & $403 \pm 50$ & $547 \pm 99$ & $611 \pm 125$ & $505 \pm 24$ & $571 \pm 112$ \\
\hline Insoluble & $778 \pm 44$ & $867 \pm 26$ & $844 \pm 204$ & $1018 \pm 35$ & $1111 \pm 159$ \\
\hline \multicolumn{6}{|c|}{ End of dark period } \\
\hline Total & $301 \pm 18$ & $571 \pm 50$ & $765 \pm 359$ & $848 \pm 336$ & $1275 \pm 340$ \\
\hline Soluble & $124 \pm 22$ & $165 \pm 6$ & $244 \pm 100$ & $222 \pm 59$ & $422 \pm 114$ \\
\hline Insoluble & $177 \pm 5$ & $406 \pm 49$ & $521 \pm 260$ & $626 \pm 277$ & $853 \pm 245$ \\
\hline
\end{tabular}

* Due to the relatively small air movement in the environmental-growth chamber, air temperatures had to be set at $15^{\circ} \mathrm{C}$ during the light period to maintain a leaf temperature of $\approx 20^{\circ} \mathrm{C}$. Plants were cultivated for $16 \mathrm{~d}$ at $33 / 25^{\circ} \mathrm{C}$ (day/night temperature) and 1500 $\mu \mathrm{mol}$ photons $\mathrm{m}^{-2} \mathrm{~s}^{-1}$. On d 16 carbohydrate contents were determined (control). Four $\mathrm{h}$ after onset of the following light period, whole plants were exposed in an environmental-growth chamber to an air temperature $15^{\circ} \mathrm{C}$ (resulting in leaf temperatures of $\approx 20^{\circ} \mathrm{C}$ ) and a light intensity of $1800 \mu \mathrm{mol}$ photons $\mathrm{m}^{-2} \mathrm{~s}^{-1}$. Data are means $\pm \mathrm{SD}(n=3)$. 


\section{ACKNOWLEDGMENTS}

This study was supported by the Deutsche Forschungsgemeinschaft (SFB 251, Universität Würzburg). We thank $M$ Lesch for technical assistance and $\mathrm{G}$ Harris for critical comments on the manuscript.

\section{REFERENCES}

Baker NR, East TM, Long SP (1983) Chilling damage to photosynthesis in young Zea mays. II. Photochemical function of thylakoids in vivo. $J$ Exp Bot 34, 189-197

Björkman O, Demmig B (1987) Photon yield of $\mathrm{O}_{2}$ evolution and chlorophyll fluorescence characteristics at $77 \mathrm{~K}$ among vascular plants of diverse origin. Planta 170, 489-504

Demmig-Adams B (1990) Carotenoids and photoprotection in plants: a role for the xanthophyll zeaxanthin. Biochim Biophys Acta 1020, 1-24

Gong $H$, Nilsen $S$ (1989) Effect of temperature on photoinhibition of photosynthesis, recovery, and turnover of the $32 \mathrm{kD}$ chloroplast protein in Lemna gibba. J Plant Physiol 135, 9-14

Greer DH (1988) Effect of temperature on photoinhibition and recovery in Actinidia deliciosa. Aust J Plant Physiol 15, 195-205

Greer DH, Berry JA, Björkman O (1986) Photoinhibition of photosynthesis in intact bean leaves: role of light and temperature, and requirement for chloroplast-protein synthesis during recovery. Planta 168, 253-260

Harris GC, Cheesbrough JK, Walker DA (1983) Effects of mannose on photosynthetic gas exchange in spinach leaf discs. Plant Physiol 71, 108-111

Kitajima M, Butler WL (1975) Quenching of chlorophyll fluorescence and primary photochemistry in chloroplasts by dibromothymoquinone. Biochim Biophys Acta 376, 105-115

Königer M, Winter K (1991) Carotenoid composition and photon-use efficiency of photosynthesis in Gossypium hirsutum $L$ grown under conditions of slightly suboptimum temperatures and high levels of irradiance. Oecologia 87, 349-356

Krause $\mathrm{GH}$, Weis $\mathrm{E}$ (1991) Chlorophyll fluorescence and photosynthesis: the basics. Annu Rev Plant Physiol Plant Mol Biol 42, 313-349

Long SP, East TM, Baker NR (1983) Chilling damage to photosynthesis in young Zea mays. I. Effect of light and temperature variations on photosynthetic $\mathrm{CO}_{2}$ assimilation. $J$ Exp Bot $34,177-188$

Martin B, Ort DR (1985) The recovery of photosynthesis in tomato subsequent to chilling exposure. Photosynth Res 6, 121-132

Metzner H, Rau H, Senger H (1965) Untersuchungen zur Synchronisierbarkeit einzelner PigmentmangelMutanten von Chlorella. Planta 65, 186-194
Morris DL (1948) Quantitative determination of carbohydrates with Dreywood's anthrone reagent. Science 497, 245-255

Musser RL, Thomas SA, Wise RR, Peeler TC, Naylor AW (1984) Chloroplast ultrastructure, chlorophyll fluorescence, and pigment composition in chillingstressed soybeans. Plant Physiol 74, 749-754

Ögren E, Öquist G, Hällgren JE (1984) Photoinhibition of photosynthesis in Lemna gibba as induced by the interaction between light and temperature. I. Photosynthesis in vivo. Physiol Plant 62, 181-186

Ögren E, Sjöström M (1990) Estimation of the effect of photoinhibition on the carbon gain in leaves of a willow canopy. Planta 181, 560-567

Öquist G, Greer DH, Ögren E (1987) Light stress at low temperature. In: Topics in Photosynthesis. Photoinhibition Vol 9 (Kyle DJ, Osmond CB, Arntzen CJ, eds) Elsevier Sci Publ, Amsterdam, 67-87

Powles SB (1984) Photoinhibition of photosynthesis induced by visible light. Annu Rev Plant Physiol $35,15-44$

Powles SB, Berry JA, Björkman O (1983) Interaction between light and chilling temperature on the inhibition of photosynthesis in chilling-sensitive plants. Plant Cell Environ 6, 117-123

Rikin A, Atsmon D, Gitler C (1979) Chilling injury in cotton (Gossypium hirsutum L): prevention by abscisic acid. Plant Cell Physiol 20, 1537-1546

Rosenqvist E, Wingsle G, Ögren E (1991) Photoinhibition of photosynthesis in intact willow leaves in response to moderate changes in light and temperature. Physiol Plant 83, 390-396

Röbbelen F (1957) Untersuchungen an strahleninduzierten Blattfarbmutanten von Arabidopsis thaliana (L). Heynh Z Indukt Abstammungs-Vererbungs/ 88, 189-252

Schreiber U, Schliwa U, Bilger W (1986) Continuous recording of photochemical and non-photochemical fluorescence quenching with a new type of modulation fluorometer. Photosynth Res 10,5162

Somersalo S, Krause GH (1990) Reversible photoinhibition of unhardened and cold-acclimated spinach leaves at chilling temperatures. Planta 180 , $181-187$

Stitt $M$ (1991) Rising $\mathrm{CO}_{2}$ levels and their potential significance for carbon flow in photosynthetic cells. Plant Cell Environ 14, 741-762

Taylor AO, Craig AS (1971) Plants under climatic stress. II. Low temperature, high light effects on chloroplast ultrastructure. Plant Physiol 47, 719725

Taylor AO, Rowley JA (1971) Plants under climatic stress. I. Low temperature, high light effects on photosynthesis. Plant Physiol 47, 713-718

Von Caemmerer S, Farquhar GD (1981) Some relationships between the biochemistry of photosynthesis and the gas exchange of leaves. Planta 153 376-387 
Walker DA, Osmond CB (1986) Measurements of photosynthesis in vivo with a leaf disc electrode: correlations between light dependence of steadystate photosynthetic $\mathrm{O}_{2}$ evolution and chlorophyll a transients. Proc $R$ Soc Lond B 227, 267-280

Winter K, Königer M (1991) Dry matter production and photosynthetic capacity of Gossypium hirsutum L under conditions of slightly suboptimum leaf temperatures and high levels of irradiance. Oecologia $87,190-197$
Winter K, Schramm MJ (1986) Analysis of stomatal and nonstomatal components in the environmental control of $\mathrm{CO}_{2}$ exchange in leaves of We/witschia mirabilis. Plant Physiol 82, 173-178

Wise RR, Naylor AW (1987) Chilling-enhanced photooxidation. The peroxidative destruction of lipids during chilling injury to photosynthesis and ultrastructure. Plant Physiol 83, 272-277

Wong SC (1979) Elevated atmospheric pressures of $\mathrm{CO}_{2}$ and plant growth. Oecologia 44, 68-74 